\title{
The Promise of Interreligious Dialogue for a World in Conflict
}

\section{Archbishop Michael Fitzgerald, M.Afr.}

\begin{abstract}
March 16, 2006
Address delivered at Boston College as part of the conference, "In Our Time: Interreligious Relations in a Divided World," co-sponsored by Brandeis Unversity and by Boston College through its Center for Christian-Jewish Learning.
\end{abstract}

My congratulations to Fr. William Leahy, president of Boston College , and Dr. Jehuda Reinharz, president of Brandeis University , on this joint initiative to celebrate the fortieth anniversary of Nostra Aetate. My thanks, too, to Cardinal-designate Sean O’Malley, archbishop of Boston, for his kind introduction.

\section{A world in conflict}

"In this age of ours, when people are drawing more closely together and the bonds of friendship between different peoples are being strengthened...". These are the opening words of the document of the Second Vatican Council, Nostra Aetate, that we are commemorating. Yet the premise for this talk, the topic that has been assigned to me, is that things are falling apart rather than coming together.

It is true that the Cold War is over. The Iron Curtain has melted away. The Berlin wall has fallen. One would hardly have imagined forty years ago that Russia (moreover no longer the Soviet Union ) would take its turn in holding the presidency of the G8. Countries that had been on opposing sides, ideologically divided, are now cooperating more and more. It could be said too that the Bamboo Curtain has lifted, at least to a great extent, as China becomes a major player with other nations in the international scene. The next Olympic Games will in some ways be a recognition that China is no longer an ostracized member of the human family.

Yet though a Third World War has been avoided, conflicts continue in the world. The Continent of Africa is far from knowing peace. We think of Congo, Ethiopia and Eritrea , Ivory Coast, Sudan (where even when a peace treaty has been signed between North and South belligerence still rages in Darfur ), Uganda where the Lord's Resistance Army wreaks havoc. Mention could also be made of Nigeria, where from time to time clashes occur between different ethnic groups often marked also by a difference of religion. In the Americas, one could think of the struggle between different armed groups in Colombia, for instance. In Asia peace has not yet come to Sri Lanka, nor in Kashmir, nor in the Southern Philippines. There is often violence too in other countries, In India, Indonesia and Pakistan . One could think too of Chechnia and of the unrest in other areas of the Caucasus . In Europe, UN troops are still needed in Kosovo. From time to time there is violence in the Basque country, and in Corsica, though it would seem that 
movements sustaining such action are losing popular support. Mention of the Middle East turns minds immediately to Iraq, but there is also the ongoing conflict between Israel and Palestine which is a running sore that prevents true peace from coming to the world. When Pope Paul VI announced in a letter that he was instituting the annual Day of Prayer for Peace in the World, a Muslim leader, Abu'l-Ala Mawdudi, founder of the Jamaat-i Islam in Pakistan, replied to this letter saying that there would be no peace in the world until the Israeli-Palestinian conflict had been settled. He would seem to have seen correctly.

There is the well know saying of Hans Küng: "There will be no peace in the world until there is peace among the religions, and there will be no peace among the religions until there is dialogue among the religions". Though there may be some truth in this saying, if it is pushed too far it becomes untrue and even unjust. Conflicts do not usually arise because of difference of religion. If the causes of conflicts are analyzed, it will be seen that more often than not they are economic, or social, or political, or racial. Yet it is true that these same conflicts can be aggravated by the difference of religion. This difference is used to set people against one another. The underlying causes become forgotten when an appeal is made to rally around a religious banner. Clashes become religious wars.

In these circumstances we may perhaps ask what interreligious dialogue can do. It may be well to state first what interreligious cannot do and should not be expected to do.

\section{What dialogue cannot do}

Interreligious dialogue should not be expected to bring an immediate solution to a conflict situation. Such a dialogue is not in the nature of a band-aid, binding wounds and bringing immediate healing. Dialogue is not a fire-brigade that can be called on to put out a conflagration. When war is raging there is usually little possibility of conducting dialogue. The conditions of equality, trust, openness are generally not present. People are not inclined to listen to one another. The solution will have to come through other means, probably through political negotiations. Religious leaders may have a role to play, encouraging people to support the envisaged solution, and if they have contact with the religious leaders of the other side, this may help. They may be able to contribute to a process which will bring about a just and adequate settlement. In writing this, I am thinking of the Alexandria process, an action started by the Archbishop of Canterbury, at that time Lord Carey, involving Jewish, Christian and Muslim religious leaders, Israeli, Palestinian and from outside the area. This action did not seem to have a great impact, but it was certainly a move in the right direction.

It should be realized, however, that interreligious dialogue is more in the nature of preventive medicine than of curative medicine. Its aim is to build up good relations among people of different religions, helping them to live in peace and harmony. This is no easy task. It entails increasing mutual knowledge, overcoming prejudices, creating trust. It means strengthening bonds of friendship and collaboration to such an extent that detrimental influences coming from outside can be resisted. 
In this sense the results of interreligious dialogue, the harmony among people of different religious allegiances, may often go unobserved. It is the conflict that makes the news, not the absence of conflict. And yet this absence of conflict is really the good news. To give but one example, in France last year there were serious riots, with much material damage done, in the cités, the lower-class residential areas of many large towns. Hardly any of this occurred in Marseille, a city which has a very large and extremely varied immigrant population. This fact did not receive much attention from the mass media, yet it would be interesting to ask why there were no riots in this particular city. One reason could be that much effort has been put into establishing good relations among the different segments of the population.

When conflict has taken place, if peace is restored, interreligious dialogue can help to maintain this peace. How can this come about? What is the Church's understanding of interreligious dialogue?

\section{The Church's understanding of dialogue according to Nostra Aetate}

\subsection{Mention of conflict}

When speaking about relations with Muslims the Declaration Nostra Aetate mentions the many "quarrels and dissensions" that have arisen over the centuries (NA 3). One thinks immediately of the Crusades, but the wars of Islamic expansion would also have to be kept in mind, those of the initial period of Islam (al-futuhât) as also the growth of the Ottoman Empire in the Balkans. To this should be added the impact of colonialism, since the European powers took control of most of the countries where Islam is dominant.

The text of Nostra Aetate was written in the early 'Sixties, before terrorism had become so prevalent and widespread. This aspect of the "quarrels and dissensions" would require mention today though it should perhaps be remembered that political assassination is not a modern phenomenon. The very term assassination is associated with the Nizari Ismailis who used this weapon against the Seljuk overlords at the end of the 11 th Century. Yet the globalization of terrorism, provoking the response of a "war on terrorism," is indeed a new feature of the world scene.

It is true that Nostra Aetate does not refer in any way to the first war between Israel and the Arab countries immediately following the declaration of the State of Israel, nor indeed to all the events which led up to this declaration, including the use of terrorism. The Council had wished to eschew any political references, and so the existence of the State of Israel received no mention at all. It contents itself with condemning "all hatreds, persecutions, displays of anti-Semitism leveled at any time or from any source against the Jews" (NA 4). This is later broadened out to a condemnation of "any discrimination against people or any harassment of them on the basis of their race, color, condition in life or religion" (NA 5).

\subsection{Suggested remedies}


What remedies are suggested to overcome this history of conflict? The Conciliar document proposes three: to forget the past, to make a sincere effort to achieve mutual understanding, and to work together to "preserve and promote peace, liberty, social justice and moral values" (NA 3 ). These can be examined separately, though they would necessarily need to go together.

\subsubsection{Forgetting the past}

One might ask whether it is really possible to forget the past. Historical events take on a symbolic meaning which may well go beyond the original incident. One has only to think of the importance of Kosovo for the Serbs. Particular rites and celebrations - the Orange Marches in Northern Ireland, for instance - keep alive the mythological significance of past history. There is no real will to forget. Westerners are often surprised to find how near to the surface the Crusades are in the consciousness of Muslims of the Middle East, combined as they are with opposition to what is felt to be the dominance of the West and the humiliation of the Islamic world.

Perhaps it was recognition of this reluctance to forget which led Pope John Paul II to suggest another way of dealing with the past. He may have been influenced in this by his own experience of the relations of his native Poland with its neighbors. What John Paul II proposed was to try to overcome the burdens of history through the purification of memories. In other words, through listening to the differing accounts of the same events, paying attention to both facts and perceptions, an attempt is made to come to a common understanding. In this exercise an effort is certainly required to avoid arguing past one another, continuing along parallel lines that will never meet. There may be a need too to demythologize so that the past is not continuously used as a weapon to arouse hatred and enmity.

When the past is examined with honesty, it will usually be seen that all is not black and white. There can be wrongs on both sides. In any case, the acknowledgement of wrongs done, of injustices, of atrocities, is an important step in any process of reconciliation. Where there is an admission of guilt, this needs to be met by a readiness to forgive. This is essential if peace is to be established among peoples that have been in conflict. It was this conviction that led Pope John Paul II to state, in one of his messages for the Day of Peace, that there can be no peace without justice, and no justice without forgiveness.

As we know, such a process is by no means easy. It can be very difficult to achieve the degree of openness which is necessary for a purification of memories to take place. I have vivid memories of two meetings which the Pontifical Council for Interreligious Dialogue and the Vatican Commission for Religious Relations with Jews organized together with the Office on InterReligious Relations and Dialogue of the World council of Churches and the World Lutheran Federation. The meetings brought together Jews, Christians and Muslims, Israelis and Palestinians for the most part, though some participants came from outside the area of the Holy Land. The topics chosen for exchange were first the spiritual significance of Jerusalem for each religion - and this is where different views of history came into play - and on the second occasion a shared view of the future. It was with much difficulty that some agreement could be found and a joint statement made, but this was achieved in the end. 
The process will obviously be easier if there exists a degree of mutual understanding. This brings me to the second suggestion.

\subsubsection{Achieving mutual understanding}

Respect is a key element of the Declaration Nostra Aetate. The document first recognizes that people look to religions for answers to "the unsolved riddles of human existence" (NA 1). Some of these fundamental questions are listed: the meaning and purpose of life; the origin of suffering; the understanding of death and what lies beyond it; the way to true happiness. Some features of religions are then highlighted: the awareness of the supreme being as taught by what may be called Traditional or Tribal religions, resulting in a deep religious sense in which harmony with nature plays a large place; the sense of divine mystery in Hinduism, explored through myth and philosophy, and the search for divine realization through ascetical practices, meditation or devotion; the way Buddhism attests to "the essential inadequacy of this changing world", and how it encourages efforts to attain to perfect liberation and supreme illumination (NA 2). Nostra Aetate does not attempt any evaluation of these different features of the various religious traditions, but it concludes with an important statement: "The Catholic Church rejects nothing that is true and holy in these religions. She has a high regard for the manner of life and conduct, the precepts and doctrines which, although differing in many ways from her own teaching, nevertheless often reflect a ray of that truth which enlightens all men" (NA 2).

Both the terms "truth" and "holy" are worth underlining. They mean that other religions cannot be dismissed as false or, even worse, as demonic. The elements of truth and holiness that they contain will be attributed by Christians to the work of the Spirit of God. These elements are to be recognized and appreciated.

Here again an effort is required to understand the other religion as it presents itself. There may often be the temptation to fasten only upon that which appears to be common, taking individual elements out of their context, neglecting the inner logic of each tradition which gives it its own specificity. While it is good to underline commonalities, there should be no fear of the differences. These differences can challenge and stimulate the followers of different traditions. True understanding will develop when people, rooted in their own tradition, open themselves up to the riches of other traditions. In this context I would like to refer to what Pope Paul VI wrote in his Apostolic Exhortation Evangelii Nuntiandi. Referring to the religions of the East he said they possess a splendid patrimony of religious writings and that they have taught generations how to pray (EN 53). It is not said explicitly, but it can be understood that those who do not belong to these religions can draw benefit from these religious writings and can also learn something for their own prayer life.

It should not be thought that this attitude of appreciation and respect must necessarily exclude any criticism. The document Dialogue and Proclamation, when treating of the dispositions for dialogue, mentions first a balanced attitude. The one entering into dialogue should be "neither ingenuous nor overly critical, but open and receptive" (DP 47). Though the Spirit of God is active in the world and in the religious traditions, these traditions are also human realities and thus are marked by weakness; sin is also at work This applies to the Christian tradition too for, as the same document points out, "notwithstanding the fullness of God's revelation in Jesus Christ, 
the way Christians sometimes understand their religion and practice it may be in need of purification" (DP 32). This leads to an interesting understanding of dialogue as illustrated in a later paragraph:

The Church encourages and fosters interreligious dialogue not only between herself and other religious traditions, but even among these religious traditions themselves. This is one way in which she fulfills her role as "sacrament, that is, sign and instrument of communion with God and unity among all people" (LG 1). She is invited by the Spirit to encourage all institutions and movements to meet, to enter into collaboration and to purify themselves in order to promote truth, and to live in holiness, justice, love and peace - dimensions of that kingdom which, at the end of time, Christ will hand over to his Father (cf. 1 Co 15:24) (DP 80).

\subsubsection{Collaboration}

In the passage just quoted mention is made of collaboration. This is the third proposal. There is certainly need for people of different religions to work together, for the challenges presented by the world we live in are so great that the combined efforts of all are needed to solve them. An allusion has been made to the globalization of terror. To overcome this there needs to be a globalization of efforts for peace.

Religions provide motivation. That is why it is important for people of different religions to tackle problems together. "End Poverty Today" is a recent campaign which is trying to get political authorities to address seriously the divide between rich and poor. Though criticized by some, the movement for fair trade is growing, following the conviction that poverty can never be eradicated until justice is established at all levels, national and international. The lack of opportunity in certain countries produces a vast wave of emigration which creates problems in the receiving countries. There is surely a need to encourage development in the countries of origin of the migrants so that they do not need to leave their countries. This was the topic addressed in a seminar held in Tripoli, Libya, earlier this month and jointly organized by the Pontifical Council for Interreligious Dialogue and the World Islamic Call Society.

A further sector where interreligious cooperation is possible is that of health. I am thinking particularly of the challenge of AIDS. In some countries, for instance in Uganda, people of different religions have been facing this challenge together. The field is vast for it includes the care of those inflicted and also preventive measures, especially through education. There will not necessarily be full agreement on the methods to be used, but sufficient nevertheless for cooperation to take place.

Other matters about which people of different religions can raise their voices together are, for instance, opposition to the proliferation of arms, the fight against corruption, the upholding of human dignity by opposing all modern forms of slavery, the defense of life, the necessity of respect for religious values.

People of different religions are meeting together to discuss these issues, and there are also interreligious movements which allow for concerted action. I am thinking in particular of the 
World Conference. Religions for Peace which for over thirty-five years, since its first Conference in Kyoto, Japan, has been facilitating common reflection and response.

A word of caution is needed. What is being proposed here is not an alliance of religions against the rest. The spirit of dialogue has to be fostered within each individual religious tradition, among the religious traditions, and between religious people and those of a secular bent. The relationship between religion and politics is a delicate one. Perhaps the best term to use would be that of a critical dialogue. Religious leaders are not called upon to formulate concrete political measures, but rather to underline basic moral principles. They need to be able to support government measures where these are seen to contribute to the common good, but also to criticize them when human dignity is not being fully respected. Politicians seem to be realizing more and more the power of religion. They wish to harness this force, sometimes for their own ends. Care needs to be taken that religion and religious sentiment are not manipulated. For this, of course, a critical distance needs to obtain between religious leaders and political powers, and this is not always the case. This is perhaps an area where religious traditions can challenge and help one another.

\section{Developing dialogue}

How can this necessary dialogue be developed? How can relations among people of different religions be strengthened? I should like now to give some suggestions. In doing so I shall follow the indications given by the documents Dialogue and Mission and Dialogue and Proclamation regarding four types of dialogue: dialogue of life, dialogue of deeds, dialogue of discourse, and dialogue of religious experience.

\subsection{Good neighborliness}

The world we live in is one marked by contradictions. On the one hand we have the phenomenon of globalization, with a great movement of peoples, instant communication, the influence of multinational corporations, the growth or expansion of new political entities, all creating a greater sense of inter-dependence. On the other hand there is a tendency for certain groups to close in on themselves, an increased regionalization, the desire for special treatment, an emphasis put on group identity. Religion can be a strong factor marking the identity of both majority and minority communities.

Interreligious dialogue aims at allowing people who belong to different religious communities to live together in peace and harmony. Particular identities are respected, but communication between individuals and groups is encouraged and promoted. There is a true dialogue of life where, as Dialogue and Proclamation puts it, "people strive to live in an open and neighborly spirit, sharing their joys and sorrows, their human problems and preoccupations" (DP 42).

Creating such a spirit means overcoming prejudices, and this in turn entails combating ignorance. It is so easy to generalize, and to class all Muslims as fundamentalists with terrorist leanings, are all Catholics as bigots, and so on. It is only when relations are established with 
individuals that the ridiculous nature of such generalizations can be appreciated. There is a terrible saying in the Philippines : "A good Muslim is a dead Muslim", but this is current particularly among those who have no direct contact with Muslims. Those who do have such contact know that Salip and Fatima are fine people, and that they can be excellent neighbors.

Good neighborliness is created by interest and concern. It can be strengthened by mutual visits to one another's homes, by offering a helping hand when someone is in need, by sharing moments of joy, such as marriages or births, or times of sadness, such as bereavements. Greeting one another on the occasion of feasts also helps people to be more united. It is for this purpose that the Pontifical Council for Interreligious Dialogue, almost from its inception, started sending a greeting to Muslims for 'Id al-Fitr, the feast that marks the end of Ramadan. In more recent years messages to Buddhists for Vesakh, and to Hindus for Diwali, have been added. These messages are sent to the local Churches with the recommendation that they be taken personally to the members of the religious community in question.

Building relationships is the name of the game. The aim should be to consolidate the local community, with all its plurality of different religious belongings, so that it will be able to resist outside influences that wish to provoke divisions. Harmony should not be taken for granted. There are examples, such as Bosnia or Indonesia , to show that mixed communities can be living in peace for a long time, but then seeds of suspicion and dissension are sown. In other words, it is when a good atmosphere reigns that the dialogue of life needs to be fostered so that people will refuse to rise up against one another.

\subsection{Organized action}

Spontaneous efforts to preserve peace are necessary and praiseworthy. They may not, however, be sufficient. There will be a need for certain structures in order to promote concerted and continued action.

It seems to me important that religious leaders know one another, for it is they who often give the tone to their respective communities through their preaching and teaching. Ecumenism has been helped by the development of clergy fraternals. These may not always be a forum for serious theological exchange, but they do provide the occasion for social contact which can lead to greater cooperation. In some places Christian clergy fraternals have been opened up to rabbis and imams. This would appear to be a good development. There may come from it reciprocal visits, of leaders or even of the communities themselves. Let me share with you a story that I heard in Chicago . One of the mosques, put up originally by a group of Bosnians, had acquired a new director who happened to be a retired university professor of Iranian origin. He decided to hold an "open day" when anyone would be allowed to visit the mosque. The members of the community were rather apprehensive, since they thought he wanted to sell the property. He reassured them that it was only so that the neighbors could see what the mosque really was and come to know the Muslim community better. One of the people who visited on this "open day" was a local rabbi. It so happened that a short time after this visit his synagogue needed refurbishing. He asked permission for the Jewish community to use part of the premises of the Islamic center for its worship during this period, and this was granted. So it happened that the 
two communities got to know each other and have continued to hold joint activities, such as Sunday picnics.

In some places interreligious councils have been formed. This is particularly true of my own country of origin, the United Kingdom . My home town, Walsall, has such a council made up of representatives of all the different religious communities. In these councils the concerns of the different communities can be aired, about educational issues, equal opportunity, discrimination, or so on. Representation can be made to the local authorities where necessary. There exists too a nation-wide Inter Faith Network the membership of which is made up of these local councils, institutes belonging to the different religions, and even individuals. This Network can make the voice of people of different religions heard at national level, and can liaise with the government.

Governments are moreover becoming more and more interested in enlisting the cooperation of the different religious communities. Their aim is to try to prevent tensions arising because of religious differences, and also, of course, to stamp out any forms of extremism which can lead to violence. The concern of the governments is understandable. They wish to know who they are dealing with and to have a valid interlocutor. Yet sometimes they would appear to overstep their role. In Belgium, France and Italy the governments have taken very active steps in setting up councils of Muslims, but these councils do not always represent all those who would assert their identity as Muslims.. They have at least the merit of getting Muslims to discuss among themselves.

Interreligious associations can also carry forward joint action. The work of the World Conference. Religions for Peace has already been mentioned. Other well established movements are the Temple of Understanding, the International Association for Religious Freedom, and the World Congress of Faiths. Another organization, the United Religions Initiative, was started in San Francisco with a somewhat controversial aim, namely to provide a body of United Religions alongside the United Nations. However praiseworthy the idea may be of allowing the religions to have a voice at the international level, the implementation of this idea runs into difficulties. How would a consensus on different issues be achieved? Who would have the authority to speak on behalf of the religions? It would seem that where URI has renounced the ambition of making pronouncements at the international level, and has concentrated in forming local clusters, much more has been achieved.

\subsection{Intellectual backing}

The dialogue of discourse can help to create better understanding and so can provide a solid foundation for common action. The exchanges will not always be on matters of belief. In fact true dialogue of a theological nature is rather rare. There is often an unwillingness to engage in such a dialogue sometimes out of misunderstanding. People are afraid that their beliefs will come under attack, whereas the aim of theological dialogue among people of different religions cannot be to do away with distinct beliefs in order to achieve unity, but rather to bring about a clearer understanding of where the differences lie. To be successful, theological dialogue requires that those engaged in it have a high degree of mutual respect and confidence. Such dialogue cannot be carried out through one off events. Continuity is needed so that the topics can be mulled over, taking all the time necessary to come to some consensus. In a chapter of a book that has just 
come out, John Borelli has described the Midwest regional dialogue between Christians and Muslims which tackled the theme of revelation. Meetings were held annually over a period of years, in a retreat environment, and led eventually to an agreed statement which noted the importance of revelation for both religions without watering down the distinct creeds. Other dialogues were held in the Mid-Atlantic region, and on the West Coast. It seems to me that one of Dr Borelli's reflections on his experience of these dialogues is worth quoting:

Interreligious dialogue is by no means based on compromise whereby parties negotiate a common ground, each giving up a little, to reach a mutually beneficial position. Compromise is important for society to work as well as it does, but giving up essential doctrines and practices is not what interreligious dialogue is about: there is no attempt to reduce two sets of belief to one or to harmonize irreconcilable differences. Nor is interreligious dialogue a debate or argument over who is right and who is wrong.

On the contrary, interreligious dialogue refers to a religious attitude that encompasses both obedience to the truth and respect for freedom of conscience.

["Recent Muslim-Catholic dialogue in the USA," in Michael L. Fitzgerald and John Borelli, Interfaith Dialogue. A Catholic View, SPCK, London/Orbis Books, Maryknoll, New York, 2006, pp. 97-109, especially pp. 100-107].

The Mid-Atlantic dialogue, just referred to, studied various aspects of marriage and family life. Christian-Muslim dialogue, and Jewish-Christian dialogue too, often concentrate on such questions of a more social nature. A series of meetings between the Pontifical Council for Interreligious Dialogue and the Al Albait Foundation of Jordan examined the following themes: the place of religion in higher education, the rights of children, women in society, the use of the earth's resources (from the dual point of view of justice and ecology), religion and nationalism. With other groups attention has been turned to questions of bioethics, religion and the mass media, the pillars of peace, and so on.

There is of course the danger that such exchanges remain theoretical. Moreover the number of participants is usually rather limited, precisely in order to permit more fruitful exchanges, so it may be felt that these meetings have little impact on society as a whole. Yet they can be seen as contributing to forge a mentality which is open to cooperation. They are helping to create that culture of dialogue which is absolutely necessary if a clash of civilizations is to be avoided.

\subsection{Spiritual backing}

I have already mentioned how the dialogue of discourse is facilitated if it is conducted in an atmosphere of prayer. The attitude of putting oneself humbly before God, of acknowledging a Truth greater than oneself, will prevent the exchange from becoming an exercise in scoring points. Prayer, meditation, the spiritual life, can become themselves the subjects of exchange. I remember a successful Christian-Muslim seminar on holiness where attention was given to the concept of holiness in each religion, the teaching about the paths to holiness, and the study of concrete examples of holy persons. Here again such exchanges can lead to a deepening of mutual 
respect. One cannot categorize Islam as merely a breeding ground for terrorists, when one finds that it has produced and can produce saintly people.

The dialogue of religious experience has developed particularly among monastics. It has flourished mainly between Buddhists and Christians, because both these religions share the tradition of monasticism. Exchanges have developed, allowing monastics of each tradition to experiment for a while life in the monasteries of the other tradition. This allows, as it were, for a growth in knowledge of this tradition from the inside. It may be thought that this type of dialogue, where silence is as important as the spoken word, is far removed from the reality of the world with all its conflicts. Yet monks can be living in the midst of violence, and they will have to discern what their role is. Let me quote again John Borelli as he describes a monastic encounter that took place in 1996 at Gethsemani, Kentucky, the monastery to which Thomas Merton belonged.

There were tense discussions of monastic witness in a world of violence. One afternoon Cistercians spoke of their brothers beheaded in Algeria just a few months earlier, giving rise to a number of serious reflections on the role of monastic life and the causes and effects of political strife. Later, when the Buddhists were at odds with one another on what to do about political situations such as Tibet and Cambodia, the discussion had taken on the character of an argument. Finally, someone asked a Cambodian monk to lead everyone in a walking meditation to the grave of Thomas Merton. This did not resolve the opposing arguments on how involved monastics truly are in the violent world around them, but the brief, prayerful walk in silence reminded them that they are on this spiritual journey together with all its hazards.["Dialogue and spirituality: The example of Buddhist-Catholic dialogue in the USA," in Interfaith Dialogue. A Catholic View, p.203].

The reference to a prayerful walk can serve as a reminder of the importance of prayer for peace. All people, of all religious traditions, are invited to be involved in this prayer. Interreligious prayer for peace was certainly encouraged by the initiative of Pope John Paul II to invite representatives of many different religious traditions to Assisi in October 1986 to pray for peace in the world. In many countries such gatherings have become quite common. John Paul II twice repeated the invitation, in 1993 to pray for peace in Europe and particularly in the Balkans, and in 2002 as a response to the tragic events of 9/11. Of course care needs to be taken to respect the conscience of each participant with regard to religious matters, but where organized with sensitivity such gatherings for prayer can be powerful experiences, binding people of different traditions together.

John Paul II was convinced of the necessity of prayer for peace, since he saw peace as a gift from God. Let me quote some of his words addressed to the participants in the 2002 gathering:

If peace is God's gift and has its source in him, where are we to seek it and how can we build it, if not in a deep and intrinsic relationship with God? To build the peace of order, justice and freedom requires, therefore, a priority commitment to prayer, which is openness, listening, dialogue, and finally union with God, the prime wellspring of true peace. 
To pray is not to escape from history and the problems which it presents. On the contrary, it is to choose to face reality not on our own, but with the strength that comes from on high, the strength of truth and love which have their ultimate source in God.

[Pontifical Council for Interreligious Dialogue, Peace: a Single Goal and a Shared Intention, Vatican City, 2002, p.91].

\section{Conclusion}

We are very conscious of living in a world of conflict, a world of violence. We may ask ourselves once more where this violence comes from. It can be provoked by jealousy, by greed, by the will to dominate. It can, of course, spring at times from frustration, when freedom of selfdetermination is denied to a people. Yet recourse to violence even in these circumstances, when it goes beyond legitimate defense and involves attacks on innocent civilians, always implies a lack of respect for human dignity and for the sanctity of life.

So where do religion and interreligious dialogue come in? Religion, as an expression of the deepest longings of the human heart, can only lead to respect for one's fellow human beings, not to the destruction of their lives. It will seek to promote the well-being of all, not the advantage of a few. It will be at the service, not of conflict, but of peace. Religion teaches us to counteract the evil tendencies that lie in the human heart: greed, lust, anger, pride. By opening up the heart to the Divine, to the Creator of all, religion brings about the realization that all human beings belong to one family. It therefore inculcates a spirit of selfless service. These values, enshrined in the different religious traditions, can come to be appreciated through interreligious dialogue.

Recourse to violence is a false way of confronting real problems. It seeks to impose a solution rather than propose one, to defeat others rather than to win them over. It breeds enmity, rather than building up friendship. Religion and interreligious dialogue, on the other hand, should lead to a search for understanding, to sympathy for those who are suffering and in need, to a thirst for justice for all, to forgiveness for wrong done, together with a readiness to acknowledge one's own wrong-doings, whether individual or collective. True religion, relayed by interreligious dialogue, does not support conflict and war, but provides the right atmosphere in which conflicts can be resolved and peace attained. 